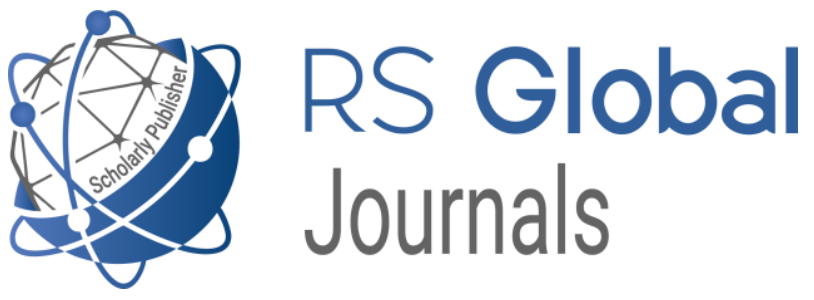

Scholarly Publisher

RS Global Sp. z O.O.

ISNI: 0000000484952390

Dolna 17, Warsaw, Poland 00-773

Tel: +48226022703

Email: editorial_office@rsglobal.pl

JOURNAL International Journal of Innovative Technologies in Social Science

p-ISSN $2544-9338$

e-ISSN

2544-9435

PUBLISHER

RS Global Sp. z O.O., Poland

ARTICLE TITLE

PSYCHOLOGICAL APPROACHES OF IMPROVEMENT OF THE EFFICIENCY OF COMMUNICATION IN THE CONDITIONS OF ANTI-CRISIS MANAGEMENT

$\operatorname{AUTHOR}(\mathbf{S})$

Vovk N. P., Diachkova O. M., Mokhnar L. I.

Vovk N. P., Diachkova O. M., Mokhnar L. I. (2021)

Psychological Approaches of Improvement of the Efficiency of

ARTICLE INFO Communication in the Conditions of Anti-Crisis Management. International Journal of Innovative Technologies in Social Science. 1(29). doi: 10.31435/rsglobal_ijitss/30032021/7414

DOI https://doi.org/10.31435/rsglobal_ijitss/30032021/7414

RECEIVED

15 December 2020

ACCEPTED

30 January 2021

PUBLISHED

05 February 2021

LICENSE

This work is licensed under a Creative Commons Attribution

4.0 International License.

(C) The author(s) 2021. This publication is an open access article. 


\title{
PSYCHOLOGICAL APPROACHES OF IMPROVEMENT OF THE EFFICIENCY OF COMMUNICATION IN THE CONDITIONS OF ANTI-CRISIS MANAGEMENT
}

\author{
Vovk N. P., PhD in Pedagogy, Associate Professor, Cherkasy Institute of Fire Safety named after \\ Chornobyl Heroes of the National University of Civil Defence of Ukraine, \\ ORCID ID: https://orcid.org/0000-0001-6601-7030
}

Diachkova O. M., PhD in Pedagogy, Cherkasy Institute of Fire Safety named after Chornobyl Heroes of the National University of Civil Defence of Ukraine,

ORCID ID: https://orcid.org/0000-0001-5164-3522

\begin{abstract}
Mokhnar L. I., PhD in Pedagogy, Cherkasy Institute of Fire Safety named after Chornobyl Heroes of the National University of Civil Defence of Ukraine,
\end{abstract}

ORCID ID: https://orcid.org/0000-0001-7753-2345

DOI: https://doi.org/10.31435/rsglobal_ijitss/30032021/7414

\section{ARTICLE INFO}

Received 15 December 2020

Accepted 30 January 2021

Published 05 February 2021

\section{KEYWORDS}

communication, social communication, information flows, anti-crisis management, crisis, emergency.

\begin{abstract}
The psychological approaches for improvement of efficiency of organization and communication in anti-crisis management, based on the explication of the concepts "crisis situation", "anti-crisis management", "social communication", "communication in a crisis", as well as based on the analysis of the application of theories and models of communication in management in emergencies are defined in the article.
\end{abstract}

Citation: Vovk N. P., Diachkova O. M., Mokhnar L. I. (2021) Psychological Approaches of Improvement of the Efficiency of Communication in the Conditions of Anti-Crisis Management. International Journal of Innovative Technologies in Social Science. 1(29). doi: 10.31435/rsglobal_ijitss/30032021/7414

Copyright: (C) 2021 Vovk N. P., Diachkova O. M., Mokhnar L. I. This is an open-access article distributed under the terms of the Creative Commons Attribution License (CC BY). The use, distribution or reproduction in other forums is permitted, provided the original author(s) or licensor are credited and that the original publication in this journal is cited, in accordance with accepted academic practice. No use, distribution or reproduction is permitted which does not comply with these terms.

Introduction. Information security of Ukraine in emergency situations is a system of decision-making of operational actions (reactions) related to the development of such situations and relief of their consequences, as well as a system of collecting and processing information about possible emergencies. Ensuring of the security of the country's information infrastructure in the case of accidents, emergencies and natural disasters is very important.

The management system in the emergencies consists of direct and coordinating bodies; control units and control centers in the emergencies; communication and information systems. In the Statute of emergency response of management bodies and units of the Operational and Rescue Service of Civil Defense we found out that the first principle of management during emergencies is continuity, which is achieved by making a decision in time and reporting main tasks to subordinate units of the Operational and Rescue Service of Civil Defense, contact with them and interacting management bodies, timely deployment of mobile control units [10].

The organization of the process of effective communication in the management process in the emergencies can be extremely difficult, and may have serious consequences. Hiding, late arrival, twist 
and destruction of the operational information, unauthorized access to it may lead to difficulties in emergencies recovery, connected with the peculiarities of information impact in extreme conditions.

A review of the literature. A number of researches studied the question of the role of communication in management in the conditions of emergency, its specificity and features. Lytvyn V.V. presented the key rules of the communication of the beat cop and its main ideas [8]; Potapchuk N.D. suggested the structural-functional model of prevention and leveling of rumors in emergency; Kotenko A. classified the threats to information security with aim to identify the boundaries of responsibility and legal competence of services and institutions whose task is to act against information and psychological influences [6]; researcher Onishchenko N.V. specified the features of communication with victims in emergencies during the psychological assistance [11]; Mokhnar L.I. offered the conditions of organization of effective dialogic interaction of future specialists of the State Emergency Service of Ukraine [9].

Some researches learned the role of communication in anti-crisis management. Barylo O.G. concerned the accuracy of the received information about the emergency influenced on the decisionmaking concerning the use of civil defence resources by the government; the researcher specified some issues related to the improvement of information support in the emergency; besides Barylo O.G. identified the possible ways to obtain timely reliable information in the emergency to make an adequate decision about the use of available means and explored efficiency as an indicator of evaluating the effectiveness of public administration in emergencies, as well as fullness and usefulness of received information [1, p. 77]; in the works of Vovk N.P. anti-crisis management is considered as a concept, the researcher presented the advantages of applying a strategic approach in management communication, the features are detailed and the factors that determine the effectiveness of the communicative process in crisis management are pointed out [2, p. 336; 3].

The aim of the article is to define the psychological approaches for improvement of efficiency of organization and communication in anti-crisis management, based on the explication of the concepts "crisis situation", "anti-crisis management", "social communication", "communication in a crisis", as well as based on the analysis of the application of theories and models of communication in management in emergencies.

Presentation of the main material. To study the process of communication in an emergency and in a crisis, there is a need to determine its structure and define in this process a number of features.

The terms "crisis situation" and "emergency situation" are very often used as synonyms, but from the point of view of public administration they should be distinguished. The crisis is a situation that is a challenge to the public imagination about the proper state of affairs, traditions, values, security, safety or the state integrity [12].

The correlation between "crisis" and "emergency" is defined as an emergency that causes or may lead to the property damage, usually on a large scale, and death, while a crisis is a critical state that extends to the entire organization (system) [7, p. 21].

In the works of researchers in the area of public administration (S.O. Huriev, A.V. Terentieva, P.B. Volianskyi) we found out that an emergency situation can be a crisis if there is a feeling that the state is not able to manage the situation. The researches noticed that this feeling may be exacerbated by the low level and quality of interaction between the executive and legislative bodies of public administration, as well as attempts by some political forces through their representatives in the legislative authority to use the situation for their own purposes [7, p. 46]. Information in the field of protection of the population and territories from man-made and natural disasters is any data about emergencies that are predicted or occurred, with their classification, limits of spread and consequences, as well as ways and methods of responding to them.

In the crisis situation there is a rapid increase of information flows, which leads in part to their uncontrollability, as it is possible to spread not only unbiased information but also targeted or false information, which leads to distortion of facts, destruction of the subject's reputation and negatively affects their perception in the mass consciousness of society.

In the crisis the well-established communication becomes especially important.

In the paper, crisis management is considered by us as a concept that provides for the solution of the following tasks: 
1) determination of a set of subprocesses of observation, detection of certain features, localization of crisis phenomena, prevention of crisis situations, determination of their features, forms of implementation;

2) determination of methods of observation, detection of certain signs, location of crisis phenomena, prevention of crisis situations;

3) formation of a set of standard situations in which observations can be made, detection of certain signs, location of crisis phenomena, crisis prevention;

4) determination of resources and their reserves to be used for observation, detection of certain signs, localization of crisis phenomena, prevention of crisis situations, and in case of their occurrence - overcoming;

5) determination of signs of stability of the system, which should be distinguished from stagnation [3].

The concept of communication in social management is defined by us as a conscious, purposeful influence on the social system as a whole or on its separate elements, which is based on the use of objective laws and trends, appropriate to this system.

In the paper we use the concept of social communication, proposed by J. Habermas; we define it as a process of communication and directed transmission of information, based on mutual understanding of the subjects of communication, which are united by a common case, needs, interests, purpose, as well as the process of interpersonal interaction, which involves active feedback, act of emotional contact [13, p. 62].

The main purpose of social communication is to establish a relationship between the subjects of society. Interruptions in communication channels both within the system (between government agencies) and externally (with non-government actors) can cause confusion and disorder, reducing the ability of situation control.

M.A. Zubarieva in the work "Applied Anti-Crisis PR-Technologies" based on the analysis of Western experience, summarized by S. Black, defines the following factors of communication use in the crisis situation:

1. An immediate response to press inquiries is needed.

2. Only known facts can be made public, guesses about the causes and victims should be avoided.

3. As soon as a sufficient amount of unpleasant news is collected, a press conference should be gathered immediately. The fullest possible information should be published on it, and all questions should be answered by the press.

4. The first persons must be present at the press conferences. Their absence makes a very bad impression. The role of the speaker requires a special attention, because his/her appearance, voice, manner of speaking will affect the audience.

5. The important part of work should be the help to the relatives of the victims, if it is a disaster where there are human losses [4, p. 15-16].

Given the significant role of communication in the anti-crisis management, recognizing the complexity of this process, its multi-vector nature and multidimensionality, we believe that communication in a crisis should be considered from the standpoint of a systematic approach, taking into account its tasks and features. According to the system approach, communication is a system in which there are: source, transmitter, channel, receiver, destination, noise. Communication means that the information source selects the desired message, the transmitter codes the message into signals, and the receiver identifies the message signals. The success of information transfer depends on the ability to truly receive messages at the place of destination.

This approach allows finding out the problems in the information transmission:

- redundancy (repetitions, copying of information),

- noise (any distortion that occurs while transmitting a signal from the source to the destination),

- feedback (corrective information from the recipient).

We also consider it necessary to study the circular model of communication proposed by W. Schramm and Ch. Osgood. Such model includes almost all fundamentally important components for crisis management: sender, recipient, coded message; decoded message; message transmission channel and communication result [14].

This model represents the communication in the form of an interactive and interpretive process, in which communicators almost simultaneously send and receive signals in the form of messages. 
In this model two especially important points for crisis management are identified:

- responsibility for the success of communication depends not only on the sender but also on the recipient;

- understanding of communication as a boundless process in space and time.

The advantages of this model use in anti-crisis management include such features:

- the circular model of communication is dynamic, with its help the process of unfolding the situation is presented;

- this model does not separate the sender and recipient, in some moment one person may be in both roles, which turns both into active participants in the interaction;

- in this model the emphasis is on feedback;

- the model shows how the correctness and accuracy of the message are necessary for its correct perception;

- circular nature allows both participants to express their points of view.

Conclusions. Consideration of the fundamental difference of management communication, which is in its purposeful and strategic nature, the approach to communication in crisis management as a system in the form of an interactive process, the use of features of the communication circular model, taking into account the factors of communication during a crisis allowed to identify a number of psychological approaches, that contain the ability of increasing the efficiency of organization and communication in the management process in a crisis situation.

The peculiarities of communication in the conditions of anti-crisis management consist in carrying out the drastic action that create a sense of competence and confirm a high level of training; providing direct answers to mass media (honest, clear, sensitive approach); absence of demagogy; establishing the partnerships without confrontation; carrying out measures to reduce social tension [3].

The main task of communication in crisis management is to ensure the continuous flow of information to groups and institutions involved in this situation in order to reduce risks and minimize fears or unwanted emotional reactions. It is important to establish contact and work with the representatives of mass media. In the process of interaction with mass media in the crisis management conditions, it is necessary to respond quickly to inquiries, publish clear, reliable information, to hold the regular press conferences with the government officials and law-enforcement authorities; careful selection and preparation for the role of speaker; organization and help provision to victims and their relatives.

The effectiveness of the communicative process in management depends on the interaction and harmonious combination of radial and communicative networks, taking into account the fundamental differences of management communication, which is in its purposeful and strategic nature; from the organic integration of communicative potential as a social practice and managerial communication as a specific context of social space.

Improvement of the effectiveness of the communication process in crisis management depends on such factors as: support the continuity and reliability of information flows, objectivity, messages validity, organization and ensuring their timely and regular transmission. The effectiveness of communication in the emergency depends on the clarity and accessibility of the information, transmitted from its clarity and specificity, providing its content with a certain algorithm in motivating action; from the use of feedback, if it is possible under the conditions of the emergency; from the construction of a communication strategy, which involves the construction and development of a communicative plan, a specific expected result; from the choice of the main strategy of informing recipients, careful and thoughtful preparation of the message text, which is aimed to a particular recipient, including gender, age, mental and emotional state, the willingness to listen, hear, understand and act in a crisis.

Thus, the explication of a number of concepts "crisis situation", "anti-crisis management", "social communication", "communication in a crisis" and the analysis of theories and models of communication in the management process in the emergency made it possible to identify a number of psychological approaches to improvement of efficiency of communication in anti-crisis management.

The review of the peculiarities of the organization and implementation of communication in anti-crisis management provides the area for further researches to improve this process, based on the considered scientific approaches. 


\section{REFERENCES}

1. Barylo O. G. Information as a component of the system of public administration in emergencies / O. G. Barylo // Investments: practice and experience. - 2011. - No 2. - P. 76-78.

2. Vovk N. P. The problem of communication efficiency in anti-crisis management / Support of civil security in Ukraine: current status and prospects: monograph / [editorial staff: O. M. Tyshchenko, T. M. Kryshtal]. Cherkasy: Publisher Chabanenko Yu. A., 2018. - 420 p., P. 332-338.

3. Vovk N. P., Pasynchuk K. M. The concept of anti-crisis management: the communicative aspect. Bulletin of the National Academy of the State Border Guard Service of Ukraine named after Bohdan Khmelnytskyi. Series: Public Administration. Khmelnytskyi, 2019. № 1.

4. Zubarieva M. A. Applied anti-crisis PR-technologies: manual / M. A. Zubarieva. - Ostrog: The National University "Ostroh Academy” Publisher, 2014. - 162 p.

5. Code of Civil Defence of Ukraine dated to 02.10.2012 № 5403-VI http://zakon4.rada.gov.ua/laws/show/5403-17.

6. Kotenko A. Classification of threats to information security to identify the boundaries of responsibility and legal competence of services / institutions. Ukrainian academic journal "Education of the region: political science, psychology of communication". - http://social-science.com.ua/article/1399.

7. Crisis management and principles of risk management in the process of emergencies liquidation: monograph / S. O. Huriev, A. V. Terentieva, P. B. Volianskyi. - K.: 2008. - 148 p.

8. Lytvyn V. V. Professional communication of patrol police officers with different population category: Legal psychology, № 1 (18), 2016 http://elar.naiau.kiev.ua/jspui/handle/123456789/1103.

9. Mokhnar L. I. Culture education of person-to-person interaction of cadets in the educational process in the establishments of higher education of State Emergency Service of Ukraine: [monograph] / L.I. Mokhnar. Cherkasy: publisher of Cherkasy Institute of Fire Safety named after the Chornobyl Heroes of National University of Civil Defence of Ukraine, 2018. - 188 p.

10. Order of the Ministry of Internal Affairs of Ukraine dated to 26.04.2018 № 340 "On approval of the Statute of Actions in Emergencies of Management Bodies and Units of the Operational Rescue Service of Civil Defense and the Statute of Actions of Management Bodies and Units of the Operational Rescue Service of Civil Protection during Firefighting”. - Access mode: https://zakon.rada.gov.ua/laws/show/z0801-18.

11. Onishchenko N. V. The main problems of the organization of emergency psychological assistance to victims in an emergency / N. V. Onishchenko, O. V. Tymchenko // Problems of extreme and crisis psychology. Collection of scientific works. Issue.10. - Kharkiv: National University of Civil Defence of Ukraine, 2011.- P. 63-70.

12. Terentieva A. V. Emergency management with elements of crisis management. - Public administration: theory and practice. - 2014. - Issue of Journal 4. - P. 172-178. - Access mode: http://nbuv.gov.ua/UJRN/Pubupr_2014_4_28.

13. Habermas Jürgen. Moral consciousness and communicative action / Translated from German - St. Petersburg: Science, 2001. $-380 \mathrm{c}$.

14. Schramm W. The Nature of Communication between Humans // The Process and Effects of Mass Communication: [Electronic resource] // http://www.fca.pucminas.br/saogabriel/raop/pdf/nature_communication.pdf. 